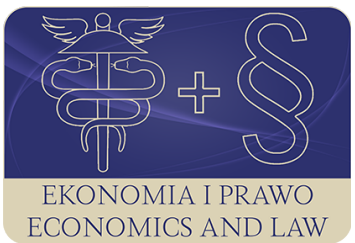

EKONOMIA I PRAWO. ECONOMICS AND LAW

Volume 18, Issue 2, June 2019

p-ISSN 1898-2255, e-ISSN 2392-1625

www.economicsandlaw.pl

EKONOMIA I PRAWO
ECONOMICS AND LAW

ORIGINAL ARTICLE

received 28.07.2018; revised 14.02.2019; accepted 30.06.2019

Citation: Buszko, M., Krupa, D., \& Chojnacka, M. (2019). Young people and banking products and services in Poland: fundamental aspects. Ekonomia i Prawo. Economics and Law, 18(2): 133-145. doi:10.12775/EiP.2019.011.

\title{
Young people and banking products and services in Poland: fundamental aspects
}

\section{MICHAE BUSZKO}

corresponding author

Nicolaus Copernicus University in Torun, Faculty of Economic Sciences and Management, Department of Finance Management, ul. Gagarina 13a, 87-100 Torun, Poland

$\square$ mibus@umk.pl

(D) orcid.org/0000-0002-1743-1902

DOROTA KRUPA

Nicolaus Copernicus University in Torun, Faculty of Economic Sciences and Management, Department of Finance Management, Poland

$\square$ dkrupa@umk.pl

orcid.org/0000-0001-9765-6871

\section{MALWINA CHOJNACKA}

Independent researcher, Poland

$\square$ m.choj@op.pl

\begin{abstract}
Motivation: This paper is devoted to the issue of using banking products and services by young people, i.e. children under the age of 13, youths from 13 to 17 years of age and young adults from 18 to 25 years of age. Considering the current fast digitalization in banking as well as increased competition on the financial market, the group of young people naturally becomes an object of interest to banks.

Aim: The work is aimed at characterising young people as the clients of banks. In particular the aim of the study is to identify the motives, terms and legal aspects of servicing young people by banks as well as to characterize reasons and frequency of using banking products and services by young people. To deepen the knowledge in scope of functioning of children youths and young adults on the market of banking products and services,
\end{abstract}


the authors of this study have taken to carry out research through literature studies, legal regulations analysis and obtaining opinions of young people in the survey.

Results: The basic motivation for servicing children, young people and young adults is linking a young client with a bank for a long period of time. Educational and social motives also exist. According to the research the majority of young people in Poland uses bank products and services. Such people start using banking offers mostly when they became adult and the share of users changes with the age, place of residence, formal education level and level of subjective financial knowledge. Young people decide to use bank products and services because of the need. They use banking products and services every day or several times per week.

Keywords: young people; bank products and services; banks; Poland JEL: G21; G41

\section{Introduction}

This paper is devoted to the issue of using banking products and services by young people, i.e. children under the age of 13 , youths from 13 to 17 years of age and young adults from 18 to 25 years of age. Servicing of the aforementioned persons by banks, as a rule, brings a relatively low level of current income for banks, but allows banks to benefit in the future, in both an economic and non-economic nature. Children, adolescents and young adults are treated as prospective clients who, at the moment of starting their professional activity, will be targeted by the bank and additionally will be a loyal group of clients. Therefore, the involvement in their servicing should be treated as a kind of investment project, the return of which will take place in the period from a few to a dozen or so years. Considering the current fast technological and IT development in banking, while changing the lifestyle of young people, manifested by the mass use of the internet and smartphones, it can be said that this group naturally becomes an object of interest to banks.

Due to the desire to deepen the knowledge of banking services for young people and youths functioning on the market of banking products and services, in particular broken down into three age categories (under 13, 13-17 and 18-25 year-olds), the authors of this study have taken to carry out research in this area through literature studies, analysis of bank offers and obtaining opinions of young people using a survey questionnaire.

The authors aimed at drawing the profiles of young people who use banking products and services. The aim of the paper was also to characterise the motivation of banks to serve young people, to analyse the legal regulations of such servicing as well as to evaluate reasons, age and the frequency of using of banking products and services by children, youths and young adults. 


\section{Literature review}

\subsection{The definition of young person and previous research on servicing young people by banks}

In the Dictionary of Polish Language, a young person is defined as someone who 'came out of childhood, but is not yet fully mature' ('young person', 2003). It is therefore a very general term, neither pointing at the age nor anthropological characteristics. Taking into account the psychological aspect, a young person can be defined through the prism of psychological periodisation of human development. This development can be divided into eight stages, of which young people will be classified as people in stages from 1 (prenatal period) to 6 (period of early adulthood) (Trempała \& Harwas-Napierała, 2004). Banking products and services for young people will in particular be offered to individuals classified in groups 3 to 6 , i.e. from the age of late childhood starting at the age of 6-7, to the period of early adulthood beginning at the age of 20-23. The stage of late child-hood is the period when a young person is able to independently use tools that enable financial services (e.g. a computer or a smartphone) and understands the meaning of basic financial concepts, e.g. savings). In turn, the stage of early adulthood means a transition period in which a person usually completes education, takes up professional activity and assumes a family, which means that they become a target client of financial institutions, classified not by age but income. It should be pointed out that based on the observation of financial practice, there is no clearly identifiable age in which a person can be considered as young. Usually, from the point of view of banks, the age of 13 is considered to be the lower limit when a person acquires limited legal capacity and may for example open a bank account ${ }^{1}$. A more serious problem is undoubtedly defining the upper age limit of people considered young. In practice, this age can be defined as 18-19 or 24-26 years depending on the level of finishing the core education.

Banking services for young people have not been the subject of widespread research in Poland so far, which, given the increasing importance of the phenomenon, justifies carrying out work in this direction. Previous studies of young people focused mainly on students and included, among others, preferences

${ }^{1}$ In Poland at the age of 13 , young people can enter into some contracts with banks. At the age of 18 they get full legal capacity, i.e. the ability to acquire rights and incur obligations. As a rule, persons who do not have legal capacity, i.e. children up to the age of 13, cannot perform legal acts except for contracts belonging to a group commonly included in minor current affairs of everyday life. Such contracts become valid only when they are executed (Civil Code, 1964). In turn, persons with limited legal capacity may perform activities through which they incur liabilities or dispose of rights, although the consent of a statutory representative, i.e. a parent or guardian is required in this case (Kidyba, 2012, p. 57). Employment of minors as juvenile employees is, as a rule, only possible after the age of 16. The mentioned age can therefore be treated as the minimum for receiving regular salary inflows into a bank account. 
in the field of internet banking, pointing to the internet as a basic criterion when choosing a bank (Soltysiak, 2015, pp. 207-218; Soltysiak \& Suraj, 2014, pp. 213-222). Investigation of young students also allowed to identify heterogeneity of the group considered and enabled the identification of several models of behavior of young clients in the banking services market (Adamczyk \& Anioła, 2011, pp. 33-35). Young people (up to 25 years of age) were also examined in terms of satisfaction with the offer and service from cooperative banks, which, among others, confirmed their high loyalty to banks (Grzybek, 2011, pp. 443-455). The behavior of young consumers in the banking services market was also examined in terms of the specific characteristics of young bank clients, the reasons for using banking services and obtaining information about banks and their offers, which enabled, among others, indicating friends and parents as the most reliable and the most widely used source of knowledge about banks and their offers (Bednarska-Olejniczak, 2012, pp. 299-311).

\subsection{Motivation of banks to service young people}

On the basis of literature research, three main motives for servicing young people by banks can be pointed out:

- gaining competitive advantage;

- influence on increasing financial knowledge among young people;

- countering the financial exclusion of young people.

When considering the motivation of servicing young people by banks, one should start with the problem of competition, which includes both the need to compete for clients with other banks, as well as with non-bank entities such as credit cooperatives or payday loan companies. One of the methods to build the potential to compete with other entities is nowadays offering products and services specifically targeted at children, young people and young adults. This activity is motivated by the desire to initiate a long-term relationship between the bank and its young clients. Its advantage is undoubtedly the fact, that it allows to tie a young person to the bank, and thus to save money in marketing expenses to acquire a client in the future. In the case of starting to receive regular income by young people, they will naturally become a target group of clients, having more complex needs and bringing a proper return for the bank. Gaining competitive advantage is often based on creating and increasing loyalty over time. Loyal clients use company's products and services more and they are less sensitive to price (Domazet et al., 2010, p. 10). Building loyalty to the bank among young people is undoubtedly a challenging issue. In times of rapid technical, IT or social progress, young people are able to adapt their everyday functioning and style of being to changes faster. They are therefore more inclined to use innovations and modern solutions than older people. Thus, it is easier for them to change the bank or use the services of many banks at the same time. Young people, however, do not show a tendency to actively use multiple accounts, change the bank or use many different types of financial institution 
services. Research on young people being bank clients show, that usually they open just one bank account, and in case of having more accounts, 71\% regularly used just one (Biskupski, 2016).

Another motive for banks to service young people is to promote financial knowledge and to establish contact with financial institutions from an early age. Financial literacy is an important component of sound financial decision-making, and many young people wish they had more financial knowledge (Lusardi et al., 2010, pp. 358-380). Thanks to such an approach, young people may be more willing to use paid financial services of the bank and more willingly and consciously choose financial products. Offering young people basic financial solutions, especially a free bank account, will help banks in the future to sell to these people other products, such as payment cards or loans. Directing the product offer especially to young people is also supposed to develop appropriate habits among them, this is beneficial from the point of view of both the economy and the banks themselves, e.g. increasing the propensity to save, planning a personal budget, encouraging them to keep money in a bank account instead of at home and use electronic billing instead of cash ${ }^{2}$.

Financial exclusion is broadly defined as a state where a people are not able to access mainstream financial services like banking facilities, credit cards or insurance policies (Carbó et al., 2005). Financial exclusion may have an external or internal character. It may come from lack of offers of financial institutions or being an effect of a decision or lack of consciousness of the client (Polasik \& Piotrowska, 2014, p. 317). Purchases by young people of products or services via the internet or mobile applications are generally only possible due to a bank account or payment card or other banking instrument of a non-cash nature. Servicing of young people is the answer of banks to the growing social and civilisation needs of young generations to use the market of goods and services. In the middle of the previous decade, only about $20 \%$ of people aged 20-25 had a current account. In the middle of the present decade, it is already around 80\% (Wilkowicz, 2015). An important phenomenon that justifies the offering of banking products and services to young people is also the decline in the age of people shopping online. According to public opinion polls, $100 \%$ of people aged 18-24 use the internet, $99 \%$ of them connect to the internet wirelessly, e.g. through a laptop, tablet or smartphone (CBOS, 2016). It is also a group that statistically spends the most time online in comparison to older people. It is assumed that currently $85 \%$ of teenagers aged 13-18 make online purchases (Inwestycje.pl, 2013). This is also influenced by the costs of delivering products purchased online, where immediate payment by bank transfer, card or smartphone has lower costs compared to the cash payment on delivery.

2 The sale of banking products and services as well as banking services for young people may also generate certain risks, including creation of a sense of easy or unrestricted access to money and excessive consumption in relation to incomes received. 


\section{Research methods}

For the purposes of this study, a survey was conducted on a sample using the CAWI method among people under 26 years of age. The subject of the research was the phenomenon of using banking products and services by young people (up to 26 years of age). The aim of the study was to determine the level of financial knowledge and methods of its acquisition by the said group, as well as an indication of the reasons and frequency of using the offers of banks, defining the type of products and services used, access channels, as well as assessing the subjective level of financial literacy of users of products and services below age 26. The survey was conducted in the period January-February 2017 using a questionnaire created on the Interankiety.pl portal, and respondents were people under 26 years of age. The link to the questionnaire was made available through a social network and blog. The questionnaire form was divided into three parts: i.e. a part containing questions for everyone, questions for persons using the banking offer and questions for persons who are non-users of banking products. The questions were closed, except for the question about the bank from which the young people used the services. During the threeweek study, 224 questionnaires were collected. 15 questionnaires were removed due to missing answers. Three questionnaires were filled in by children with the help of third parties ${ }^{3}$.

In this paper there will be presented the introduction to the survey. The main part of the survey research will be presented in the paper entitled Young people and banking products and services in Poland: the results of empirical studies.

The authors investigated the statistical significance of dependencies between variables using IBM SPSS Statistics (ver. 25) at $\alpha=0.05$.

\section{Results}

All the participants of the survey were asked about their use or non-use of banking products and services. $74 \%$ declared using the offer of banks, and $26 \%$ declared non-use. The results of the survey confirm, that young people in general use banking products and services. Table 1 presents the structure of the group of respondents as well as the test of proportions for categorial variables in columns (non-users and users of banking products) versus categorial variables such as gender, age, place of residence, level of education, subjective perception of level of financial knowledge and source of financial knowledge.

The results presented in the table 1 indicate that statistically the use of banks offers is related to the age, place of residence, level of formal education as well as subjective level of financial knowledge ${ }^{4}$. Gender and source of financial knowledge turned out to not be statistically significant at $\alpha=0.05$. The results confirm

\footnotetext{
${ }^{3}$ Help consisted in providing content in a more accessible way.

4 P-values of Chi square tests were $<0.001$.
} 
that respondents in the age 22-25 are in the majority of users of banking products against other age groups. In turn, persons below 18 are mostly non-users. The age 18-21 can be considered as a crossover period between being a non-user and user of banking products. The research indicates that residents of big cities $(100-500 \mathrm{~K})$ are proportionally the main users of banking offers against the residents of small cities $(<100 \mathrm{~K})$ who are proportional non-users. People having formal higher or higher economic education ${ }^{5}$ are mostly the users of banking products while people with primary and gymnasium education are proportional non-users. Secondary and vocational education can be considered then as the transitional level. Proportionally respondents having a good level of financial knowledge are statistical users of banking products against respondents with a lack or poor level of financial knowledge who are non-users.

When analysing the using of banking offers by children, adolescents and young adults (154 of 209 participants of survey) one could find that the major growth of interest in banking products and services is during the ending years in secondary school or the first years in high school. Such a period is the most active for starting relations with banks. Chart 1 . shows the structure of the ages when the young people start using banking offers.

Although the predominant part of 154 respondents indicated the age range of 18-21 as the time of commencement of using banking services, it should be emphasised that about $40 \%$ of respondents declared that they started this process even before reaching maturity. This result may confirm the significant potential to use banking offers among children and adolescents before reaching their full legal capacity ${ }^{6}$.

The research also addressed the issue of the reasons why young people started using banking products and services (chart 2).

Definitely the most important factor to start using a banks offer was the need (e.g. payment for shopping, transferring the funds, keeping money safe), not just the recommendation of banking products and services by friends or promotional activities of banks (paying benefits, giving free cinema tickets, etc.). The dominance of the need as the motivation to start using banking product and services may confirm a significant financial participation of the young people in the internet or mobile environment. The interesting fact is that young people are not motivated by the recommendations of friends or other persons in starting the using of bank products and services but the choice of the bank itself is usually recommended by those who already use bank offers.

5 The detailed characteristics of the system of education in Poland are provided by Smoczyńska (2014, p. 7).

${ }^{6}$ The statistical analysis with Chi square test $\alpha=0.05$, contingency coefficient and Spearman Rho confirmed statistical significance just of dependence between the age of the starting of using banking products and the age of respondents $(p<0.001, C=393$, Rho=0.204), formal education level $(p=0.005, C=0.366$, Rho=0.139) and frequency of using bank products and services $(p=0.006, C=0.416$, Rho=0.176). 
Young people using banking services were asked about the bank brand that supports them. Such a question had to check if young people have a preferred bank or if they use offers of a particular group of banks. The respondents listed in total 20 banks and in general pointed to the biggest banks in Poland (PKO BP SA, BZ WBK SA, mBank SA, Bank Millennium SA, ING Bank Śląski SA). The mentioned banks are classified within the top 10 biggest banks in Poland. The highest share was had by PKO BP SA which is the leading bank in Poland (chart 3$)^{7}$.

The persons participating in the study were also asked to indicate the frequency of using banking products and services. The largest number of indications, $42 \%$, use banking products and services several times a week, $30 \%$ every day, and $6 \%$ once a month or less. The obtained answers indicate that if young people decide to use the bank's offer, they usually do it on a regular basis. The distribution of responses to the considered aspect is shown in chart $4^{8}$.

\section{Conclusion}

Linking a young client with a bank for a long period of time becomes the basic motivation for servicing children, young people and young adults. It is also possible to achieve several important educational or social benefits. Starting the professional activity of young people causes them to be re-qualified to the bank's target group of clients, which allows the bank to generate a correspondingly high income. Due to the above conditions, the majority of banks in Poland have an offer of products and services addressed specifically to young clients.

A survey conducted on a group of 209 respondents indicated the relatively large use of banking services and products by young people. One could observe the dependence between the use of banking services and the age, place of residence, formal education level and level of financial knowledge. Gender and source of financial knowledge turned out to be not statistically significant.

In general, children and youths under 18 who used banks' products were in a minority. Using of banking offers by young adults (from 18 to 21) was more common and this age can be considered as a transitional period. The group of people of 22-25 years was dominated by the users of banking products and services. Similarly, the dominance of users is visible among highly educated

7 The statistical analysis with Chi square test at $\alpha=0.05$ did not confirm a statistical significance of the dependence between the bank brand and gender, age, level of formal education, place of residence of respondents, level and source of financial knowledge, age of first adoption of banking products or the frequency of using banking products.

8 The statistical analysis with Chi square test $\alpha=0.05$, contingency coefficient and Spearman Rho confirmed a statistical significance of dependence between the frequency of using bank products and services and gender $(p=0.014, C=0.292)$, age $(p<0.001$, $C=0.494, R h o=0.379)$, education level $(p<0.001, C=0.456, R h o=0.336)$ and place of residence of respondents $(p=0.020, C=0.394$, $R h o=0.217$ ). 
people. The increased commonness of using of banking products and services observed for older and well-educated respondents can be explained primarily by the need, especially in the sphere of payments, but not by fashion or promotions of bank products. A relatively large proportion of young people participating in the survey indicated that they started using banking services before they reached the age of maturity. This result justifies banks taking action towards preparing an offer specifically for young people. Research has also highlighted the fact that young people actively use products and services, which means that if a young person decides to cooperate with a bank, they usually use the offer frequently. Such use creates the potential for generating future benefits to banks. Banks, whose services are used by young people, are first of all the largest universal banks in Poland with well-known brands, although the possession of accounts in cooperative banks is also found. In fact, there is no statistical dependence between choice of the bank and the gender, age, place of residence, level of formal education and level and source of financial knowledge.

Taking into account the advances in technology, access to mobile devices and the development of applications, one should expect an increase in the activity of banks in servicing people aged 13-17. Increasingly common access to information, affiliation to the online community and the desire to be like other peers causes that young people realise that the lack of having an account in some way determines their exclusion, for example, by the lack of the possibility of shopping online.

\section{References}

Adamczyk, G., \& Anioła, P. (2011). Klasyfikacja typów zachowań ludzi młodych na rynku usług bankowych z zastosowaniem wielowymiarowych metod analizy danych. Marketing i Rynek, 18(10).

Bednarska-Olejniczak, D. (2012). Zachowania młodych konsumentów na rynku usług bankowych. Zeszyty Naukowe Wyższej Szkoty Bankowej we Wroctawiu, 31.

Biskupski, Z. (2016). Banki kochają mtodych klientów. Ze wzajemnością. Retrieved 14.02.2019 from https://strefabiznesu.pl.

Carbó, S., Gardner, E., \& Molyneux, P. (2005). Financial exclusion. New York: Palgrave Macmillan.

CBOS. (2016). Korzystanie z internetu. Komunikat z badań nr 92. Retrieved 14.02.2019 from https://www.cbos.pl.

Domazet, I., Zubović, J., \& Jeločnik, M. (2010). Development of long-term relationship with clients in financial sector companies as a source of competitive advantage. Petroleum-Gas University of Ploiesti Bulletin. Economic Sciences Series, 62(2).

Grzybek, M. (2011). Satysfakcja młodych usługobiorców z oferty i obsługi banków spółdzielczych. Zeszyty Naukowe Uniwersytetu Szczecinskiego. Ekonomiczne Problemy Ustug, 72. 
Inwestycje.pl. (2013). Nastolatki kupuja w sieci. Retrieved 14.02.2019 from http://inwestycje.pl.

Kidyba, A. (2012). Kodeks cywilny. Komentarz. Tom I. Część ogólna. Warszawa: Wolters Kluwer.

Lusardi, A., Mitchell, O., \& Curto, V. (2010). Financial literacy among the young. Journal of Consumer Affairs, 44(2). doi:10.1111/j.1745-6606.2010.01173.x.

Polasik, M., \& Piotrowska A. (2014). Transakcyjne wykluczenie finansowe w Polsce w świetle badań empirycznych. Prace Naukowe Uniwersytetu Ekonomicznego we Wroctawiu, 330. doi:10.15611/pn.2014.330.34.

Smoczyńska, A. (Ed.). (2014). The system of education in Poland. Warsaw: Foundation for the Development of the Education System.

Soltysiak, M. (2015). Preferencje młodych klientów banków w zakresie bankowości internetowej. Kwartalnik Kolegium Ekonomiczno-Spotecznego. Studia i Prace, 3(2).

Soltysiak, M., \& Suraj, M. (2014). Internet banking awareness and preferences among young people in Poland. Humanities and Social Sciences, 21(3). doi:10.7862/rz.2014.hss.48.

Trempała, J., \& Harwas-Napierała, B. (2004). Psychologia rozwoju cztowieka. Charakterystyka okresów życia cztowieka. Tom 2. Warszawa: PWN.

Ustawa z dnia 23 kwietnia 1964 r. - Kodeks cywilny [Civil Code of April 23, 1964] (Dz.U. $1964 \mathrm{nr} 16$ poz. 93) (Poland).

Wilkowicz, Ł. (2015). Millennium, mBank, ING. Bankowi liderzy i reszta świata. Ranking. Retrieved 14.02.2019 from https://gospodarka.dziennik.pl.

Young person. (2003). In Nowy stownik języka polskiego. Warszawa: PWN.

\section{Acknowledgements}

Author contributions: authors have given an approval to the final version of the article. Authors contributed to this work as follows: M.B. and D.K. developed the concept and designed the study, M.C. collected the data, M.B. and D.K. analysed and interpreted the data, M.B. prepared draft of article, D.K. revised the article critically for important intellectual content.

Funding: this research was funded by the Nicolaus Copernicus University in Torun, Faculty of Economic Sciences and Management, Department of Finance Management statutory sources.

Note: the results of this study were presented at 25th EBES Conference (May, 23-25, Berlin, Germany). Some part of the data was used by Malwina Chojnacka in her master thesis. 


\section{Appendix}

Table 1.

Structure of the group of respondents and the test of proportions in columns

\begin{tabular}{|c|c|c|c|}
\hline Variable & Category & Non-users (A) & Users (B) \\
\hline \multirow{2}{*}{ gender } & male & 10 & 23 \\
\hline & female & 45 & 131 \\
\hline \multirow{3}{*}{ age } & $<18$ & $31\left(\mathrm{~B}^{* * *}\right)$ & 14 \\
\hline & $18-21$ & 18 & 42 \\
\hline & $22-25$ & 6 & $98\left(\mathrm{~A}^{* * *}\right)$ \\
\hline \multirow{4}{*}{ place of residence } & countryside & 25 & 61 \\
\hline & city $<100 k$ & $23\left(\mathrm{~B}^{* *}\right)$ & 31 \\
\hline & city $100-500 \mathrm{k}$ & 4 & $50\left(\mathrm{~A}^{* * *}\right)$ \\
\hline & city $>500 k$ & 3 & 12 \\
\hline \multirow{4}{*}{ level of formal education } & primary \& gymnasium & $36\left(\mathrm{~B}^{* * *}\right)$ & 14 \\
\hline & secondary \& vocational & 16 & 61 \\
\hline & high & 1 & $37\left(\mathrm{~A}^{* * *}\right)$ \\
\hline & high economic & 2 & $42\left(\mathrm{~A}^{* * *}\right)$ \\
\hline \multirow{5}{*}{ level of financial knowledge } & lack \& poor & $24\left(\mathrm{~B}^{* * *}\right)$ & 16 \\
\hline & general & 8 & 30 \\
\hline & average & 15 & 48 \\
\hline & good & 7 & $46\left(\mathrm{~A}^{*}\right)$ \\
\hline & very good & 1 & 14 \\
\hline \multirow{4}{*}{ source of financial knowledge } & parents \& friends & 18 & 31 \\
\hline & books, press, TV & 2 & 10 \\
\hline & school \& college & 15 & 60 \\
\hline & internet & 20 & 53 \\
\hline
\end{tabular}

Notes:

*** $p$-value $<0.001,{ }^{* *} p$-value $<0.01,{ }^{*} p$-value $<0.05$.

$N=209$, single choice.

Source: Own study based on a survey. 


\section{Chart 1.}

The structure of the ages of young people, which start to use banking products and services (in \%)

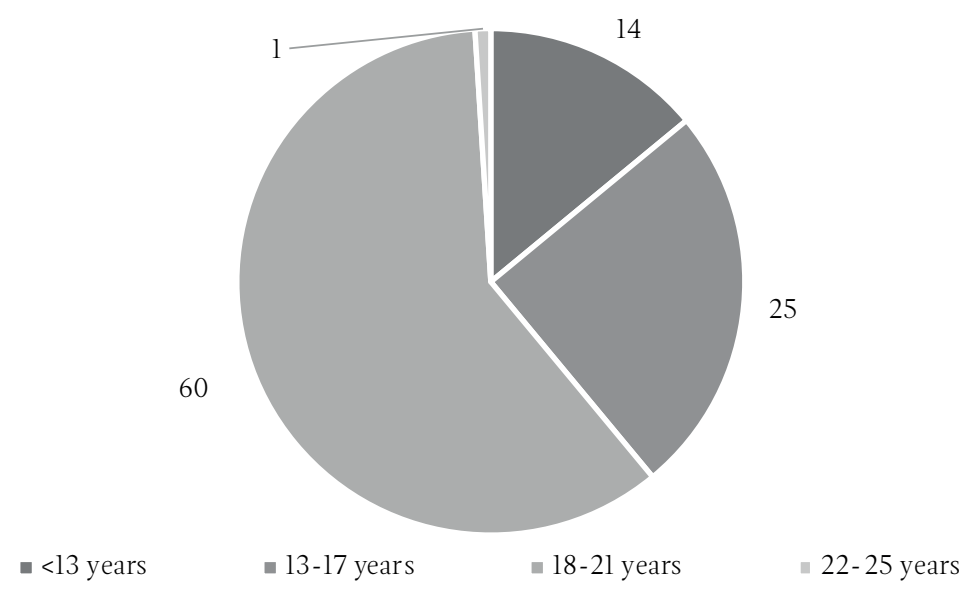

Notes:

$N=154$, single choice.

Source: Own study based on a survey.

\section{Chart 2.}

The reason of starting to use banking products and services (in \%)

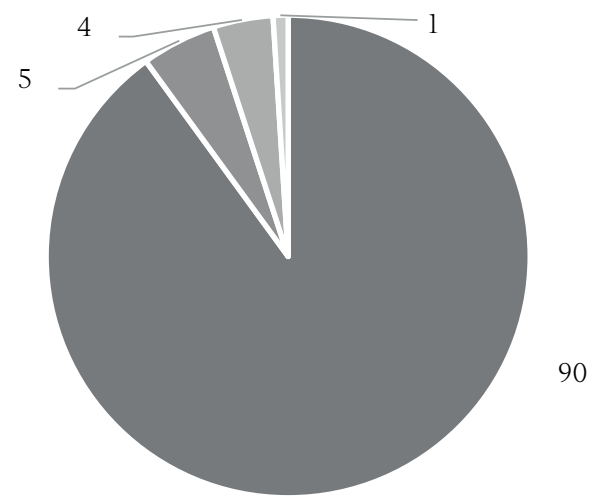

- need - promotion of the bank - reccomendation/following the others $\backsim$ image of the bank

\section{Notes:}

$N=154$, single choice.

Source: Own study based on a survey. 


\section{Chart 3.}

Banks from which young people used offers (in \%)

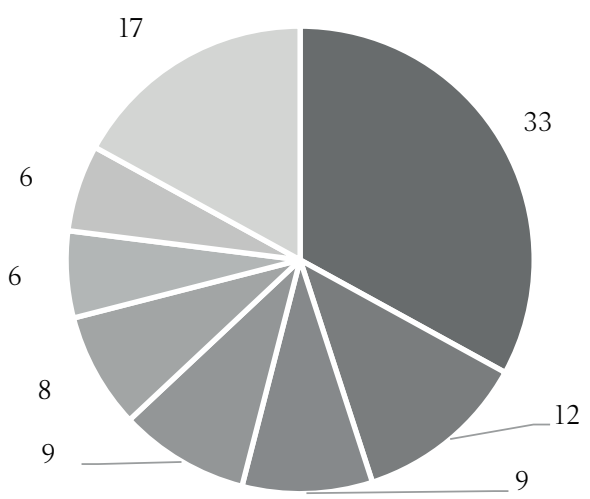

$$
\begin{aligned}
& \text { - PKO BP SA } \\
& \text { - BZ WBK SA } \\
& \text { - mBank SA } \\
& \text { - ING Bank Śląski SA } \\
& \text { - Bank Spółdzielczy } \\
& \text { - Pekao SA }
\end{aligned}
$$

Notes:

$N=154$, single choice.

Source: Own study based on a survey.

\section{Chart 4.}

Frequency of using banking products and services (in \%)

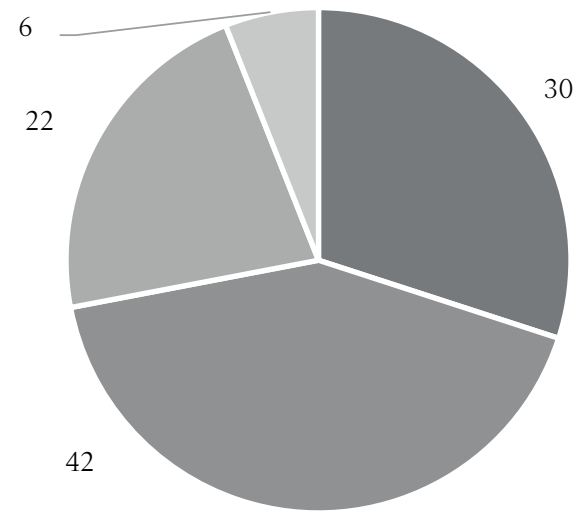

- every day $\quad$ several times per week $\square$ several times per month $\quad$ once a month or less

\section{Notes:}

$N=154$, single choice.

Source: Own study based on a survey. 
